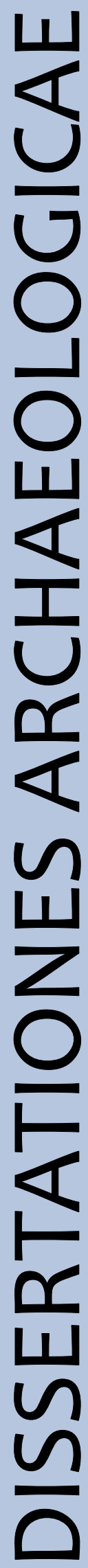

ex Instituto Archaeologico Universitatis de Rolando Eötvös nominatae
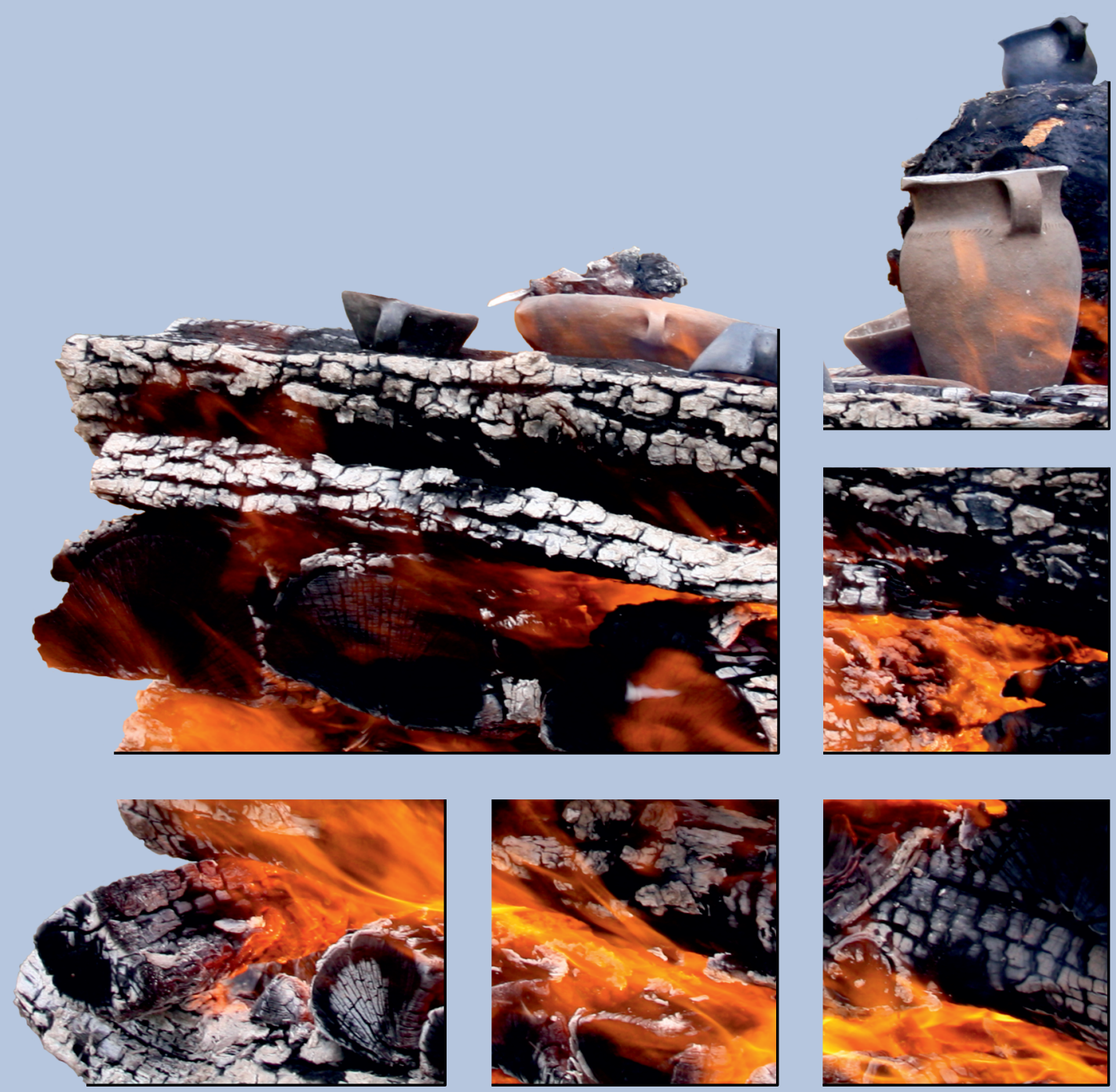

$$
\text { Ser。 3. No } 0_{0} \sigma_{0} \mid 2018
$$




\section{Dissertationes Archaeologicae ex Instituto Archaeologico}

Universitatis de Rolando Eötvös nominatae Ser. 3. No. 6.

Budapest 2018 


\section{Dissertationes Archaeologicae ex Instituto Archaeologico}

Universitatis de Rolando Eötvös nominatae Ser. 3. No. 6.

Editor-in-chief:

DÁvid BARTUS

Editorial board:

LÁsZló BARTOSIEWICZ

LÁSZLÓ BORHY

ZOLTÁN CZAJLIK

ISTVÁN FELD

GÁBOR KALLA

PÁL RACZKY

MiKLÓS SZABÓ

Tivadar Vida

Technical editor:

GÁBOR VÁcZI

Proofreading:

ZsófIA KondÉ

SzILVIA BARTUS-SzÖLLősI

Aviable online at http://dissarch.elte.hu

Contact: dissarch@btk.elte.hu

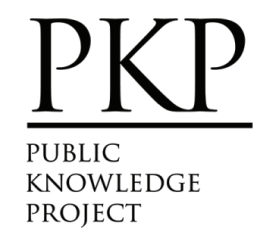

๑ E Eötvös Loránd University, Institute of Archaeological Sciences

Layout and cover design: Gábor Váczi

Budapest 2018 


\section{CONTENTS}

Zsolt Mester

In memoriam facques Tixier (1925-2018)

\section{ARTICLES}

Katalin SEBőK

On the possibilities of interpreting Neolithic pottery - Az újkökori kerámia értelmezési lehetőségeiről

András FüZESI - Pál RACZKY

Öcsöd-Kováshalom. Potscape of a Late Neolithic site in the Tisza region

Katalin SEBőK - Norbert FARAgó

Theory into practice: basic connections and stylistic affiliations of the Late Neolithic settlement at Pusztataskony-Ledence 1

Eszter Solnay

Early Copper Age Graves from Polgár-Nagy-Kasziba

László GuCsi - Nóra Szabó

Examination and possible interpretations of a Middle Bronze Age structured deposition

Kristóf FÜLÖP

Why is it so rare and random to find pyre sites? Two cremation experiments to understand the characteristics of pyre sites and their investigational possibilities

Gábor János TARBAY

"Looted Warriors" from Eastern Europe

Péter MogYoRós

Pre-Scythian burial in Tiszakürt

Szilvia JoHÁczi

A New Method in the Attribution? Attempts of the Employment of Geometric Morphometrics in the Attribution of Late Archaic Attic Lekythoi 
The Roman aqueduct of Brigetio

Lajos JuHÁsz

A republican plated denarius from Aquincum

Barbara HAJDU

Terra sigillata from the territory of the civil town of Brigetio

Krisztina HoppÁL - István VIDA - Shinatria AdHityatAma - Lu Yahui 461

'All that glitters is not Roman'. Roman coins discovered in East Java, Indonesia.

A study on new data with an overview on other coins discovered beyond India

\section{FIELD REPORTS}

Zsolt MESTER - Ferenc CSERPÁK - Norbert FARAGÓ

Preliminary report on the excavation at Andornaktálya-Marinka in 2018

Kristóf FÜLÖP - Denisa M. LÖNHARDT - Nóra SZABÓ - Gábor VÁcZI

Preliminary report on the excavation of the site Tiszakürt-Zsilke-tanya

Bence Simon - Szilvia JohÁcZI - Zita KIS

Short report on a rescue excavation of a prehistoric and Árpádian Age site near Tura

(Pest County, Hungary)

Zoltán CzAJlik - Katalin NovinszKi-Groma - László RupNIK - András BöDőcs - et al. 527

Archaeological investigations on the Süttö plateau in 2018

Dávid BARTus - László BORHY - Szilvia JoHÁczi - Emese SzÁMADó

Short report on the excavations in the legionary fortress of Brigetio (2017-2018)

Bence Simon - Szilvia JoháczI

Short report on the rescue excavations in the Roman Age Barbaricum near Abony

(Pest County, Hungary)

Szabolcs Balázs NAGY

Recent excavations at the medieval castle of Bánd 


\section{Thesis Abstracts}

Rita JENEY

Lost Collection from a Lost River: Interpreting Sir Aurel Stein's "Sarasvatī Tour" in the History of South Asian Archaeology

István VIDA

The Chronology of the Marcomannic-Sarmatian wars. The Danubian wars of Marcus Aurelius in the light of numismatics

Zsófia MASEK

Settlement History of the Middle Tisza Region in the $4^{\text {th }}-6^{\text {th }}$ centuries AD.

According to the Evaluation of the Material from Rákóczifalva-Bagi-földek 5-8-8A sites

Alpár Doвоs

Transformations of the human communities in the eastern part of the Carpathian Basin between the middle of the $5^{\text {th }}$ and $7^{\text {th }}$ century. Row-grave cemeteries in Transylvania, Partium and Banat 


\title{
Short report on a rescue excavation of a prehistoric and Árpádian Age site near Tura (Pest County, Hungary)
}

\author{
BENCE Simon \\ Institute of Archaeological Sciences \\ Eötvös Loránd University \\ simonben.c@gmail.com
}

\author{
SzILVIA JohÁczi \\ Institute of Archaeological Sciences \\ Eötvös Loránd University \\ johi.sziszi@gmail.com \\ ZITA KIS \\ Institute of Archaeological Sciences \\ Eötvös Loránd University \\ zitus.kis@gmail.com
}

\begin{abstract}
The staff of the Institute of Archaeological Sciences of Eötvös Loránd University conducted a rescue excavation in the northern territory of Tura (Pest County, Hungary) in the spring and autumn of 2018. The works revealed settlement and burial features of the Late Bronze and Early Iron Age, settlement features of the Árpádian Age, one feature from the early modern period, and some traces of military activity in the Second World War. The unexpected scientific novelty of the excavation is the discovery of an extensive Árpádian Age settlement and a brick oven in one of the pit-houses.
\end{abstract}

\section{Introduction}

The staff of the Institute of Archaeological Sciences of Eötvös Loránd University ${ }^{1}$ conducted a rescue excavation in connection with the redevelopment of the Gödöllö-Hatvan railway track as subcontractor of the Ferenczy Museum Center on commission of the Budavári Estate Development and Operation Office in the northern territory of Tura (Pest County, Hungary) between $22^{\text {nd }}$ May $-25^{\text {th }}$ June and $15^{\text {th }}$ October $-11^{\text {th }}$ November 2018 . On the opened $19345 \mathrm{~m}^{2}$ surface the excavation unearthed settlement and burial features of the Late Bronze and Early Iron Age, settlement features of the Árpádian Age, one feature from the early modern period, and some traces of military activity in the Second World War.

As the finalization of the documentation and the restoration of the field material is still an ongoing process the present report only highlights the most noteworthy features and finds of the excavations.

1 The excavation was conducted by Bence Simon (ELTE Institute of Archaeological Sciences, Department of Classical and Provincial Archaeology). We hereby say thanks to the staff of the excavation: Anita Benes (PhD student, ELTE), Szilvia Joháczi (PhD student, ELTE), Zita Kis (ELTE Institute of Archaeological Sciences, Department of Classical and Provincial Archaeology), László Rupnik (HAS-ELTE Interdisciplinary Research Group of Archaeological Sciences), Csilla Sáró (HAS-ELTE Interdisciplinary Research Group of Archaeological Sciences) archaeologists, Ferenc Barna (MA student, ELTE), Rebeka Gergácz (MA student, ELTE) technicians. 


\section{The site and its research history}

The excavated site extends in the northern parts of the modern territory of Tura (Pest County, Hungary) along a mild, south-west facing slope in the northern neighbourhood of the railway on the eastern bank of the Emse Brook, where it turns south and runs into the Galga River (Fig. 1). Tura, Határ-völgyi-dülő is located in the Hatvan Plain micro-region, ${ }^{2}$ which is mainly characterized by fertile Chernozem brown forest soil making the environment perfect for agriculture. The field was also known as Fekete-dűlö, and the Határ-völgy as Gyüri-völgy in the $19^{\text {th }}$ century (Fig. 2).

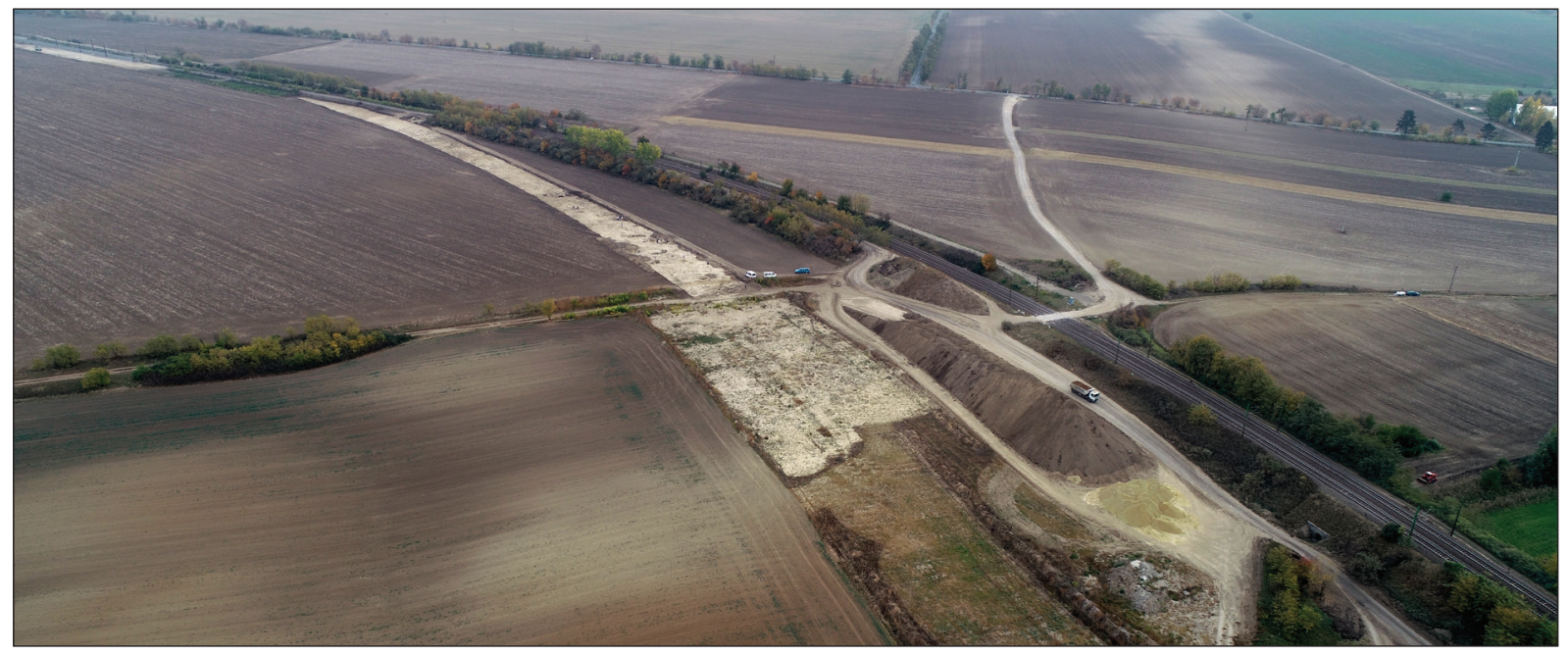

Fig. 1. Drone photo of the excavation taken from above the Hosszú-völgy.

The site was identified and mentioned by Mátyás Szőke in his thesis observing the prehistoric settlement history of the Galga Valley. After his field-walking, Klára Kővári, Zsuzsa Miklós and István Torma collected archaeological material between 1979 and 1981 from the Neolithic, Late Bronze Age, Migration period and the Árpádian Age. ${ }^{3}$ In 2011, Csaba Szalontai prepared an impact study for the preliminary archaeological documentation in connection with the redevelopment of the Gödöllö-Hatvan railway track. ${ }^{4}$ As the area contained archaeological remains, Katalin Kovács (Ferenczy Museum Centre) conducted a test excavation with three trenches in winter of 2017/2018, during which Late Bronze Age urn burials, settlement features (pits and ditches), constructions from the Celtic Age, and an Árpádian Age blacksmith's forge (?) came to light. Based on these observations we expected a dense site.

\section{Course of the excavation}

The excavation was conducted in two phases during which we investigated $19345 \mathrm{~m}^{2}$ and revealed 499 features of five different historical periods. We started the excavation $22^{\text {nd }}$ May and we opened an area near the top of the hill on the eastern side of the Emse Brook, and finished this section $25^{\text {th }}$ June 2018. In autumn we continued the works and started the eastern section $15^{\text {th }}$ September and finished it $10^{\text {th }}$ November. During this phase, the area between the Emse

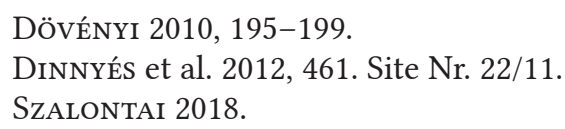


Brook and the surface opened in spring was also designated for archaeological prospection, however, only one feature was uncovered here. At the same time, the confines of the site had to be enlarged to the east from the north-south running dirt-road, as - based on a prompt field-walking - it became probable that further features could be expected underground. This notion was confirmed as the top-soil was removed. We received a moderately dense surface, and the area was qualified as a rescue excavation.

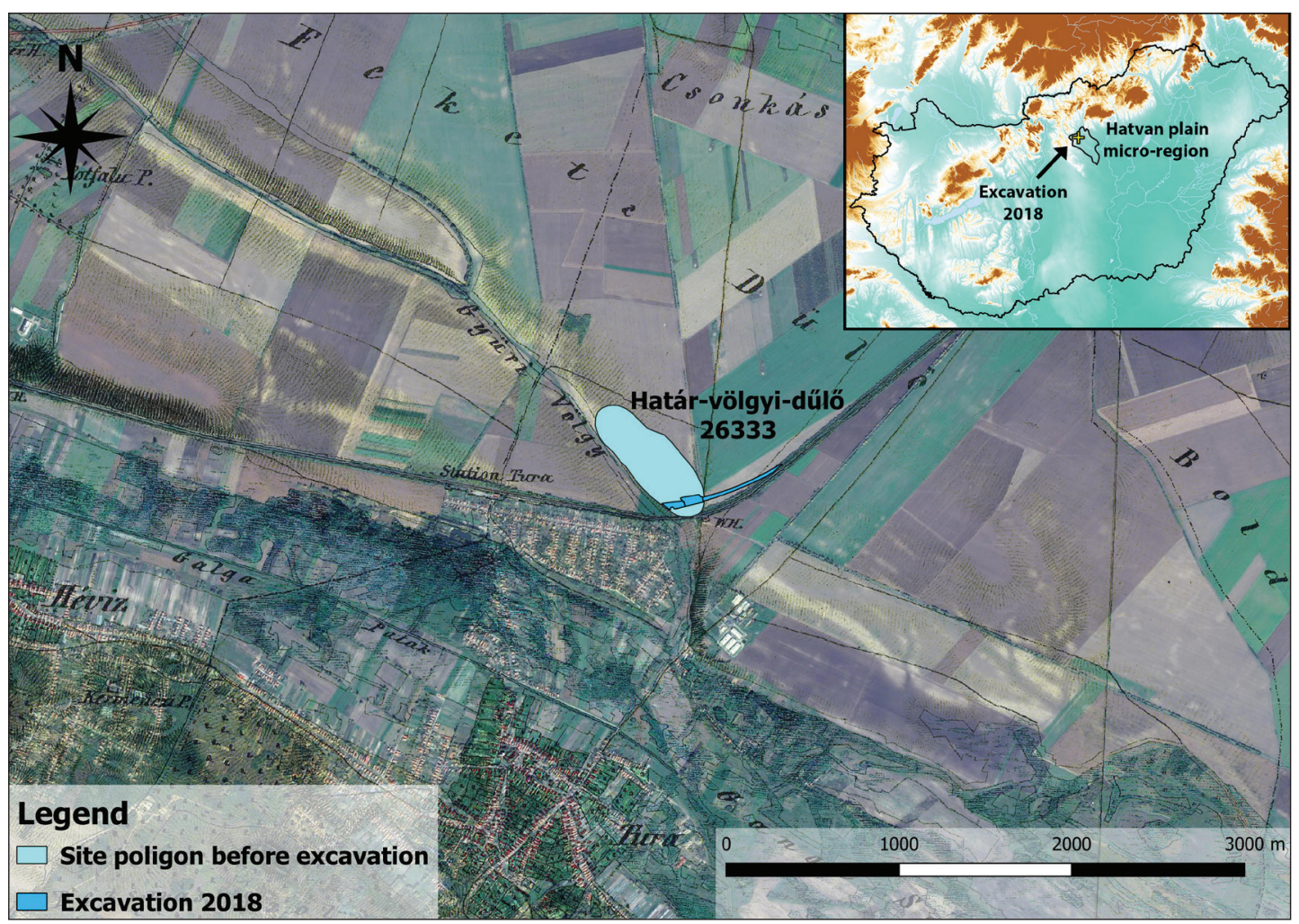

Fig. 2. Location of the excavation on synchronized Google Earth ${ }^{\mathrm{TM}}$ and Second Military Survey map.

During the top-soil removal we observed that the mixed, dark brown humus on the gentle slope of the valley became thinner as we came to the dirt-road on the top, but it became thicker again on its eastern side. The yellowish subsoil was only $30-50 \mathrm{~cm}$ below surface, which made the mechanized earthwork difficult and dangerous for the urn burials appearing already in the dark humus. The damage inflicted by ploughing shattered the pottery vessels of the urn burials. We also noticed some parallel running ditches perpendicular to the slope in the western section of the road, and some in the eastern part, close to the road (Fig. 3). These marks can be associated with contemporary cultivation. On the eastern side the subsoil appeared to be deeper, around 50-60 cm below surface. The confines of the archaeological features were satisfactorily recognizable only in this depth, but in the section-wall of the excavation their contours were still identifiable $40 \mathrm{~cm}$ under the surface.

The western part of the excavated track until the steeper slope of the hill was lacking any archaeological features. On the already moderate slope of the hill the archaeological features were densely queueing and after a brief empty part they came to light in great numbers again. East of the dirt-road, the surface was not as dense as the west facing slope. The excavation revealed features of the Late Bronze and Early Iron Age, Árpádian Age, early modern period and some traces of military activity in the Second World War. 


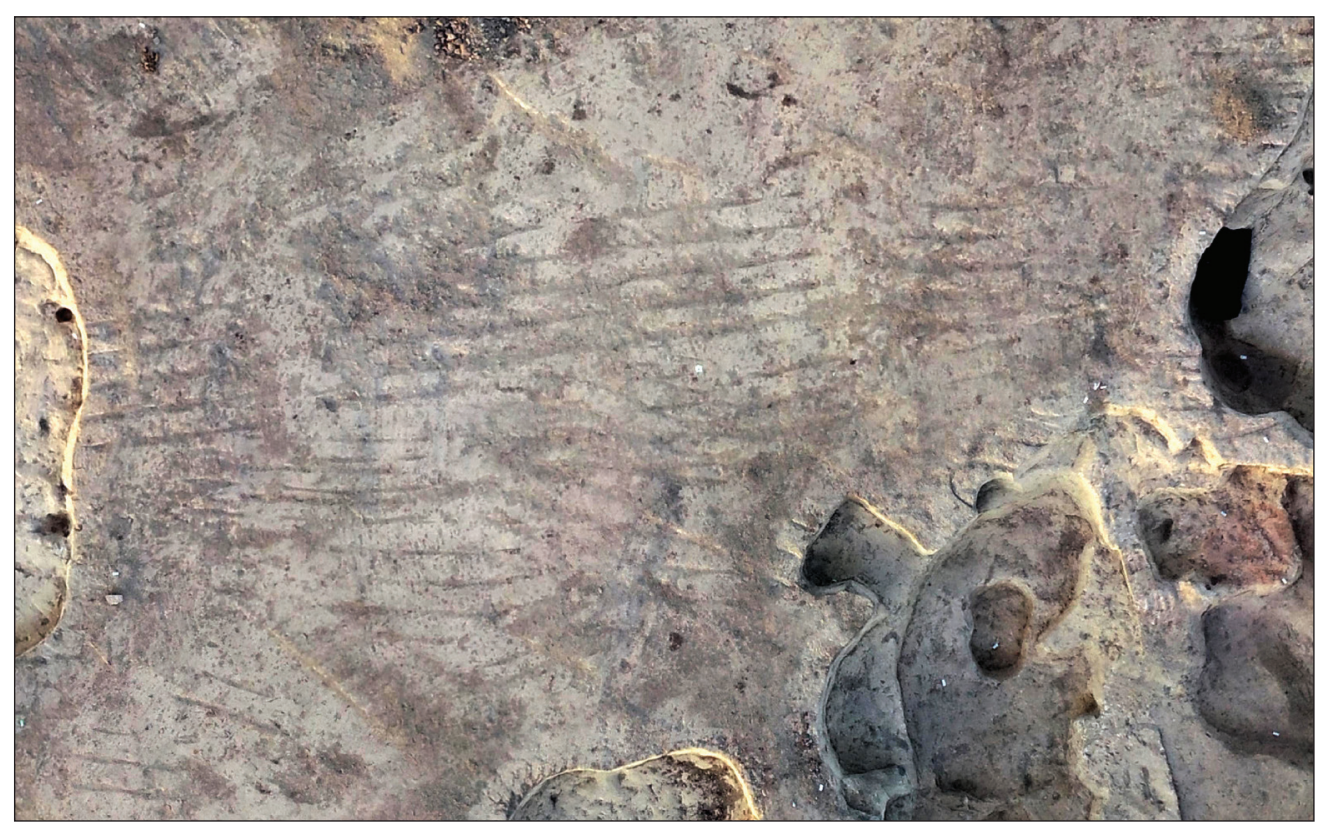

Fig. 3. Traces of contemporary cultivation on the excavation.

Our work was assisted by friends of the Ferenczy Museum Center who searched for metal objects throughout the excavation. ${ }^{5}$ Unfortunately the excavated track did not yield many metal objects; only some bronze wire probably from the Bronze Age burials, an important Árpádian Age coin, and other bronze objects from the same period are worth mentioning.

\section{Prehistoric period}

Most of the features belonged to the Late Bronze or Early Iron Age. During the excavation we did not recognize any typical material that could decisively enable us to differentiate between the mentioned ages. This will probably change after the cleaning and restoration of the material, which is currently an ongoing process. In the western section (Fig. 4) of the site we could observe superposition only in a few instances. The most obvious one was the superposition of a ditch over many prehistoric features (Fig. 4.1). It crosses the excavation area from the east and turns south-west and fades away on the moderately steep slope. Unfortunately, this feature did not produce any find material that could help us in its dating. It could be from the Árpádian Age or even from the Modern Age.

The Late Bronze Age or Early Iron Age settlement was confined by a single ditch from the west and by three from the hilltop in the east (Fig. 4.2-3). We collected prehistoric pottery from each of the ditches, which could point to their contemporary existence. This can only be questioned if we take the pit from the early modern period as an example, which we will discuss later. Anyway, the intensity of the prehistoric features decreased and were of another quality outside the ditches. The settlement is continuous from the hilltop to the east.

On the hill-side we excavated six 2-3 m deep beehive-shaped pits that contained only a modest material. In this western section altogether thirteen structures came to light that were of various shapes: round, oval and rectangular. In three structures an oven or fireplace was 
documented. The fill of two structures contained several fragments of quern and millstones. We collected millstones from fifteen features altogether. Besides the stone material, the backfill of the structures could be characterized by rich pottery shards, spindle-whorls and stone tools in some cases.

From the hilltop to the east, except for the three confining ditches, the prehistoric features were not densely populated, but they were more extensive (Fig. 5.1). In the close neighbourhood of the dirt-road a deep pit was excavated, with the same amount of meagre material as we had seen on the other side. Two pit-complexes came to light in this eastern section, and both produced abundant archaeological finds, and even a round oven was unearthed in one of them. Apart from these features we identified four round or oval dwellings with post holes in the centre or on the sides (Fig. 6). We collected pottery shards and animal bones from their filling.

In accordance with the results of the test excavation, we detected urn-burials only in the north-eastern part of the western section, where twenty-one of these ensembles were located (Fig. 4.4). The vessels contained barely any ashes or other objects besides the pottery (Fig. 7). Only a fragment of an obsidian blade, ${ }^{6}$ a bronze ring and some wires are worth mentioning. The graves were severely damaged by looters and agriculture, well before the excavation. Apart from the urns, a deceased was buried on its side in a pit, besides which three other inhumation burials came to light. Unfortunately, none was furnished with grave goods. As the inhumations did not intersect any other features, they can probably be connected to the prehistoric period.

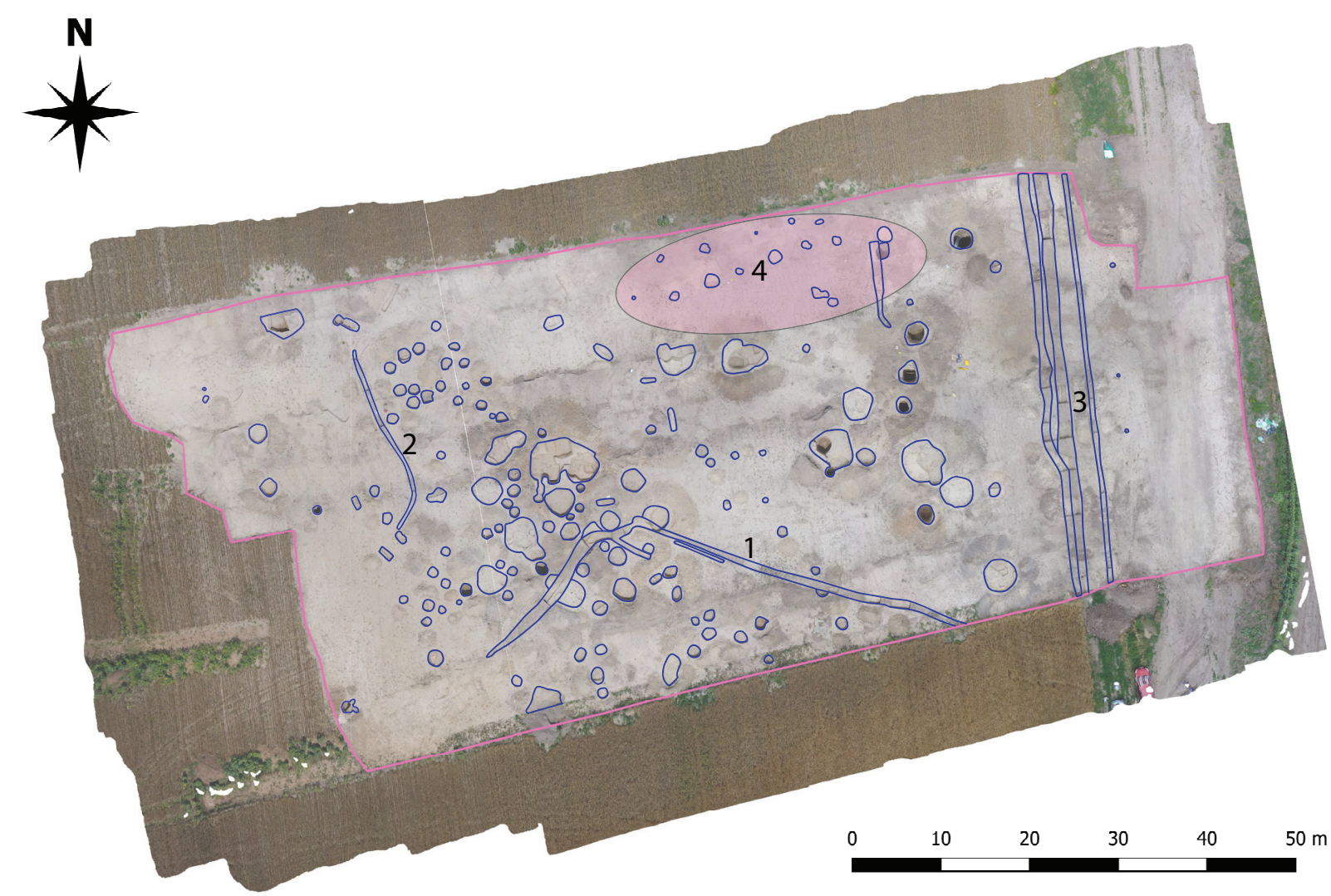

Fig. 4. Western section of the excavation with the features of the prehistoric settlement and burials.

6 The material of the blade probably originates from modern day Slovakia. I hereby say thanks to Norbert Faragó (ELTE - Institute of Archaeological Sciences) for his help in the identification of the fragment. 
1
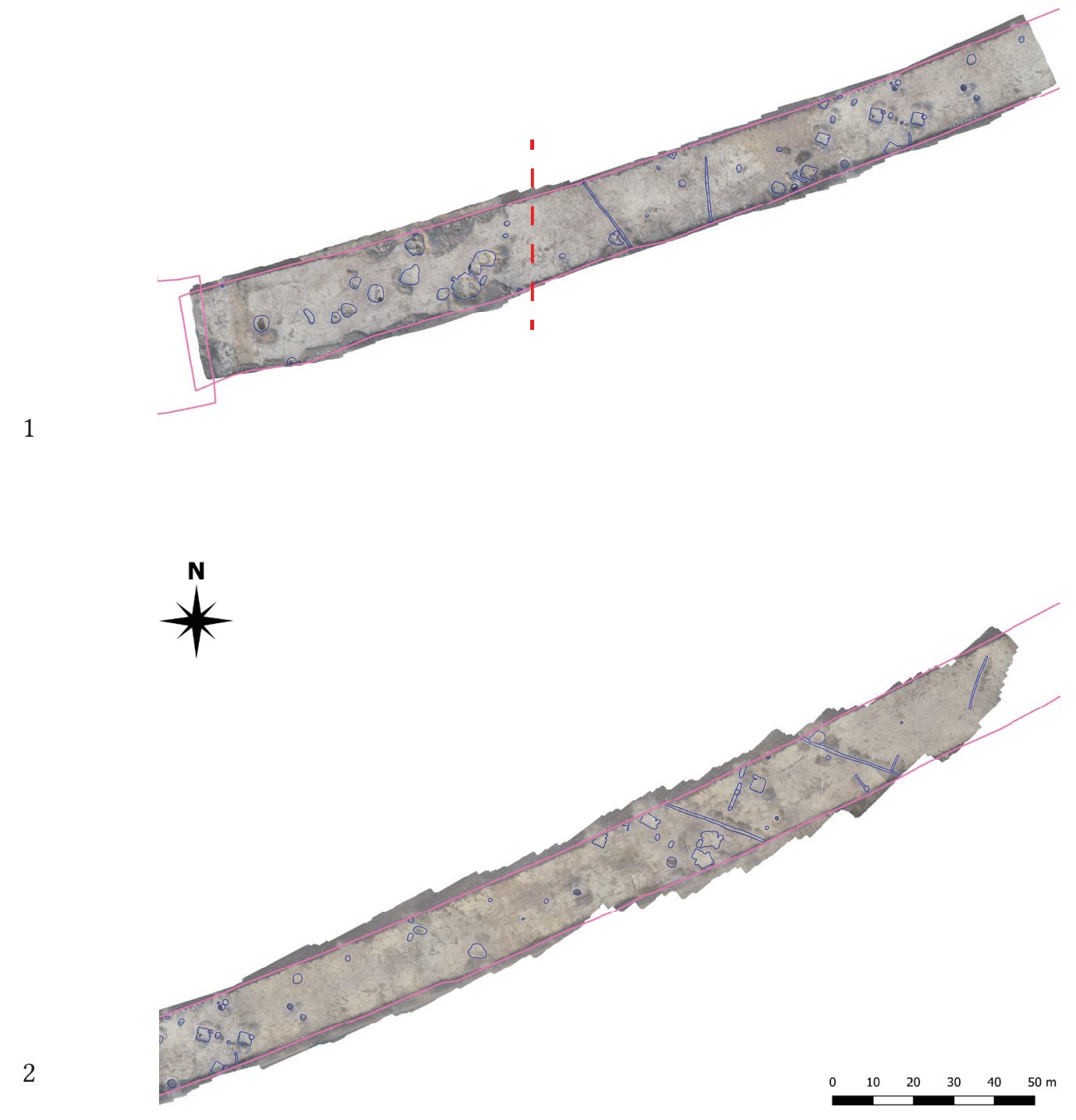

Fig. 5. 1-2 - Eastern section of the excavation. East of the red line starts the Árpádian Age settlement.
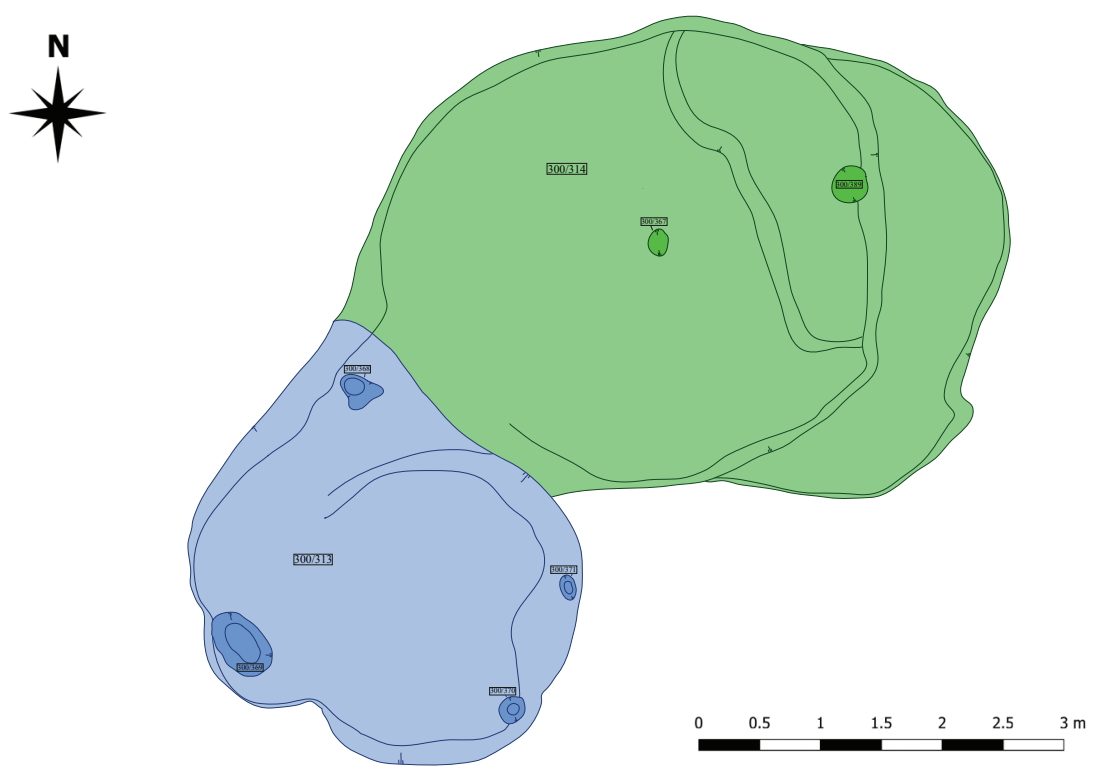

Fig. 6. Plan of two prehistoric houses built right next to each other. 


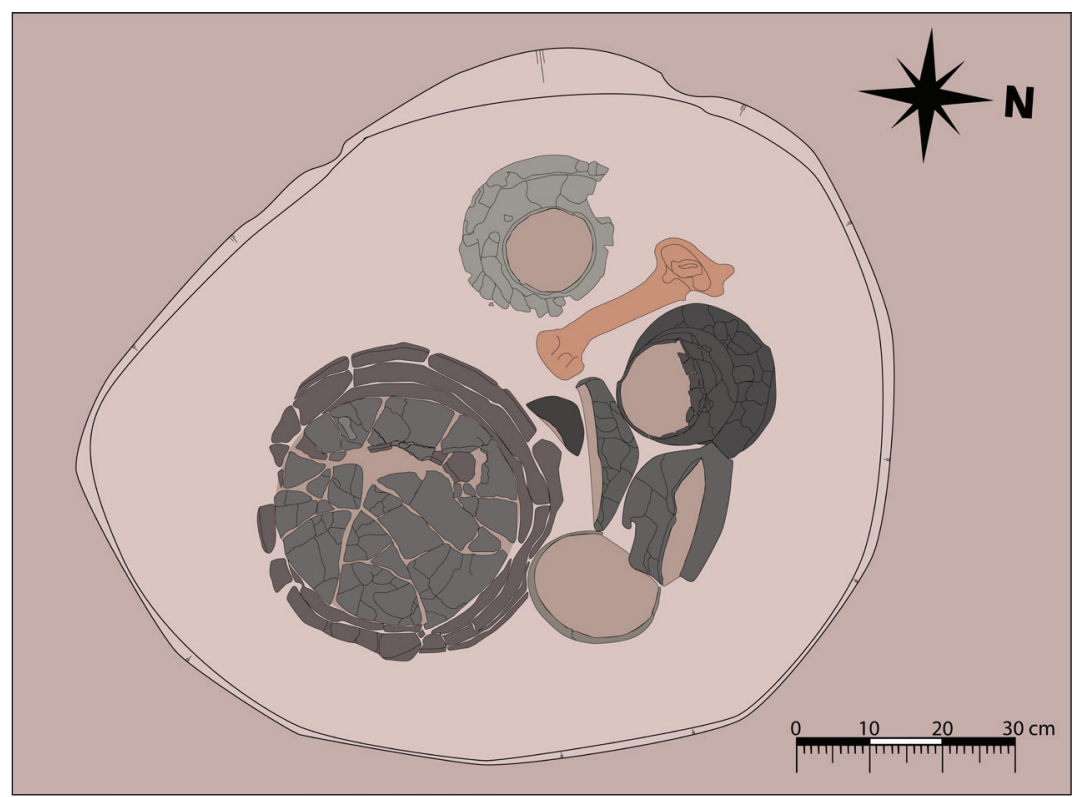

Fig. 7. Drawing of a Late Bronze Age urn burial of nine vessels of various forms.

\section{Árpádian Age}

Proceeding to the east the features of the Bronze Age and Early Iron Age settlement disappear and they are succeeded by ditches, pits and houses from the Árpádian Age (Fig. 5.1). Many of the backfill of the features were grey with ash, which would suggest the swift abandonment of the settlement. ${ }^{7}$ We excavated thirteen semi-subterranean pit-houses during the autumn campaign. Three of these were partly outside the opened area. Each of the houses were built with a baking/heating oven that were positioned in the north-eastern corner of the square or rectangular houses. We found that in two cases these ovens had been renewed. In most of the cases the posts holding the roofing were placed along the middle axis, next to the shorter sides. The structure of the settlement seems to be planned, in which ditches divided alike-oriented houses or house-groups (Fig. 8).

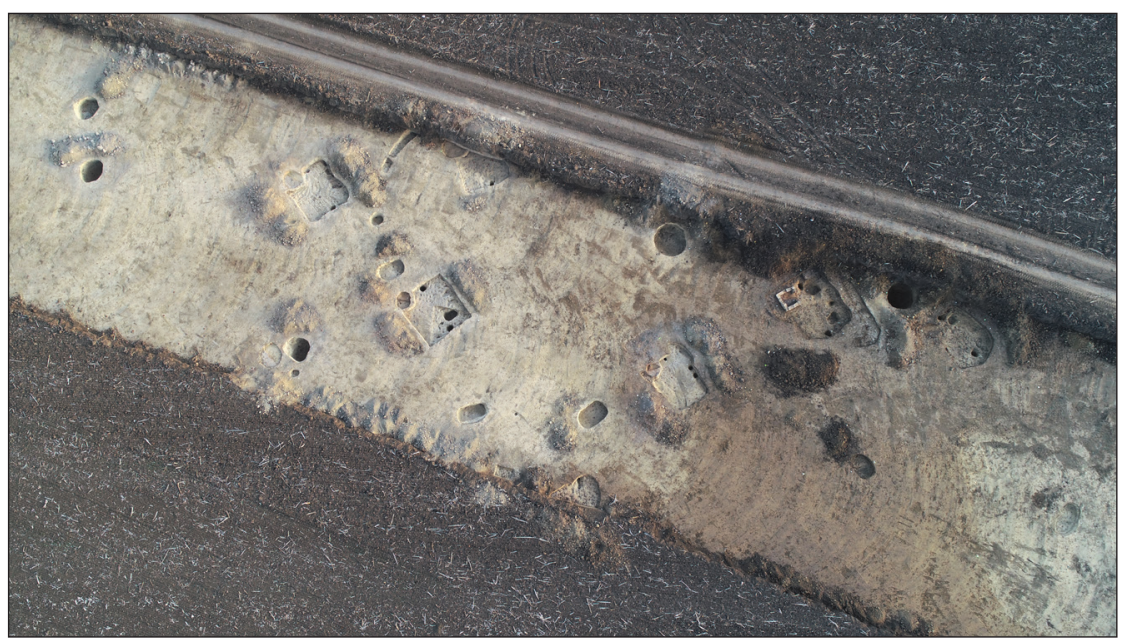

Fig. 8. Árpádian Age house-lines in the middle of the excavation's eastern section.

7 Some patches of ash were also visible during the field-walkings. DinnYÉs et al. 2012, 461. 
In one of the houses, we uncovered a rare brick oven where normally the oven should have been found (Fig. 9). It was nearly square, $100 \times 110 \mathrm{~cm}$, and six rows of bricks were still standing. Each layer of bricks ${ }^{8}$ was put into yellow clay, which became red from the heat on the inside (Fig. 10). The inner side was not thickly plastered, it was only $1 \mathrm{~cm}$ thick. Unfortunately, the upper structure did not survive, and it did not collapse into the hearth either. Interestingly, some bricks came to light near and farther from the features, which could indicate the contemporary abandonment of the settlement. ${ }^{9}$ In the past months, we have only found two settlements from Middle Age Hungary where brick ovens had been unearthed. Many of these ovens are from the late $11^{\text {th }}$ century Szer village, ${ }^{10}$ and one is from a $12^{\text {th }}$ century village on the territory of Makó. ${ }^{11}$ Based on the analogies and the only datable coin ${ }^{12}$ from the excavation, our oven and the whole settlement can be dated to the $12^{\text {th }}$ century. For preservation and possible exhibition, we disassembled the oven layer by layer, during which two footprints of a dog came to light on one of the bricks (Fig. 11).

Next to the houses and in their neighbourhood, we uncovered twelve ditches with a U-shaped cross-section. Only one produced any material, but the others can be probably dated to the Árpádian Age. Their orientation is mostly northwest-south-

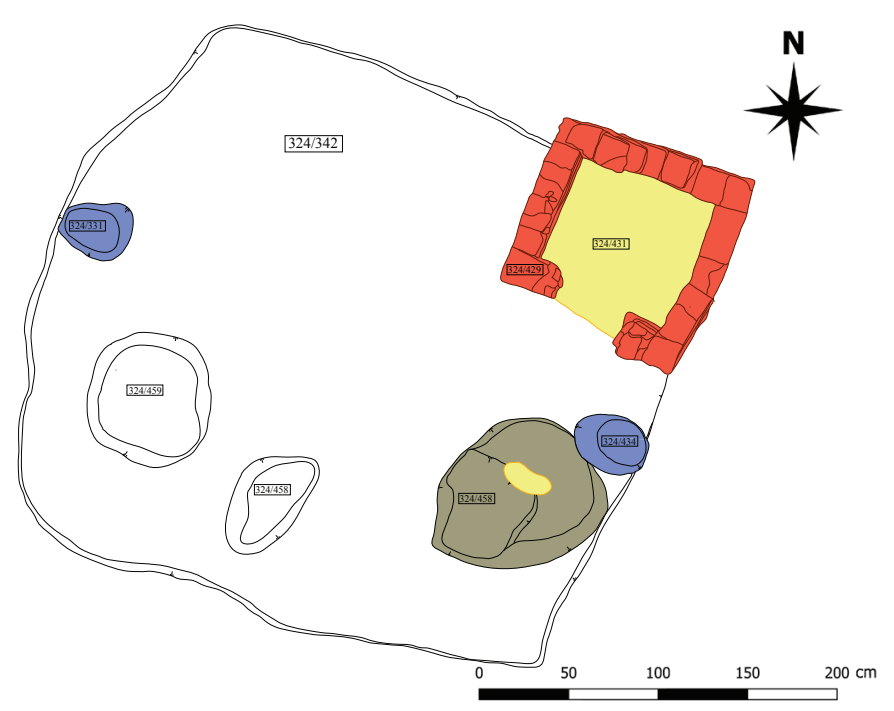

Fig. 9. Plan of an Árpádian Age pit-house with the brick oven in the north-eastern corner.

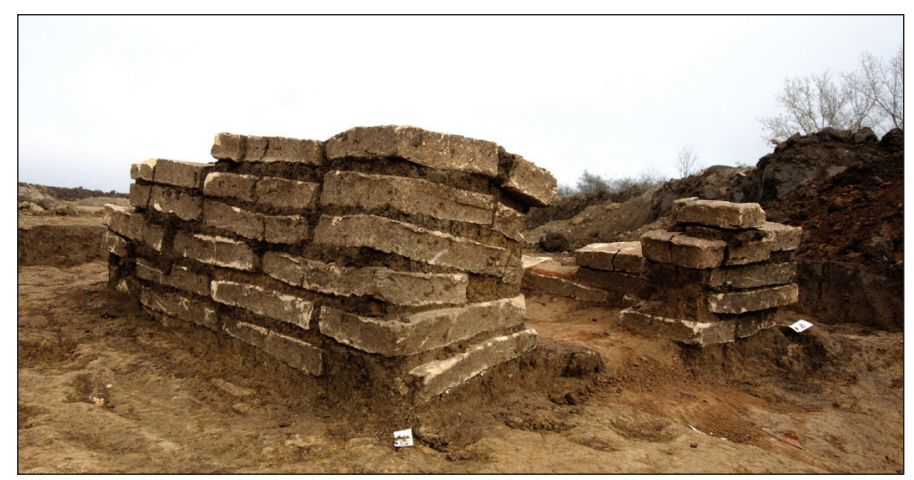

Fig. 10. View of the brick oven from the west.

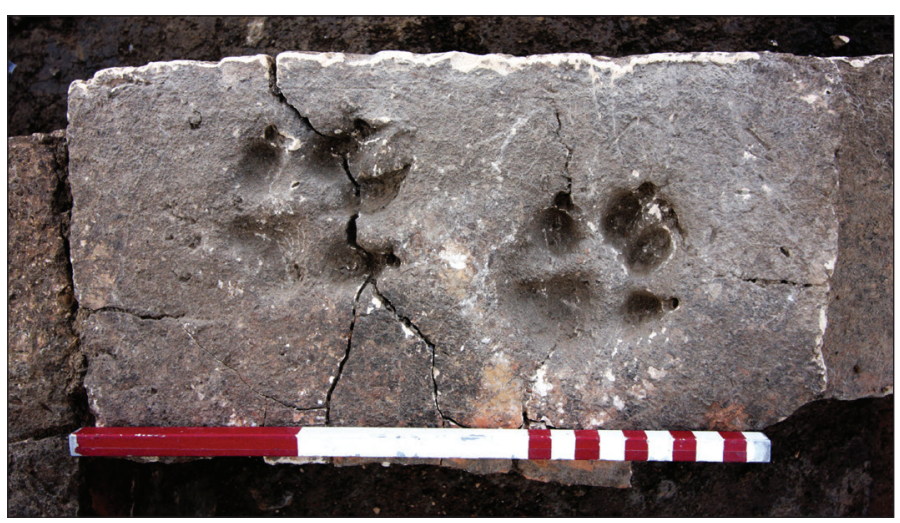

Fig. 11. Footprints of a dog in one of the Árpádian Age bricks.

8 Measures of the bricks: $31 \times 17 \times 4.5 \mathrm{~cm}$.

9 Their relationship with the bricks of the oven needs to be investigated with natural scientific methods sometime in the future.

10 BÉRES 1982; VÁLYi 1986; VÁLYi 1992.

11 Herendi - SósKuti 2016, 34.

12 See below. 
east or perpendicular to it, and only one ditch is facing the north-south direction. Twenty-eight pits of the same period were excavated besides them.

Apart from the brick oven we did not come across any peculiar feature or material. Although a silver coin from the $12^{\text {th }}$ century was found next to one of the prehistoric pit-complexes, unfortunately it was not decisively from the exploited soil or from the level of the ploughland..$^{13}$ Only a cross-shaped bronze object can be mentioned, which can possibly be a strap distributor of a horse equipment. The pottery material was dominated by grey vessels the shoulders of which were decorated with wavy lines or incised patterns. It will be interesting to compare the structures and the material of the settlement with the excavated site of the same period on the western side of the Emse Brook. ${ }^{14}$

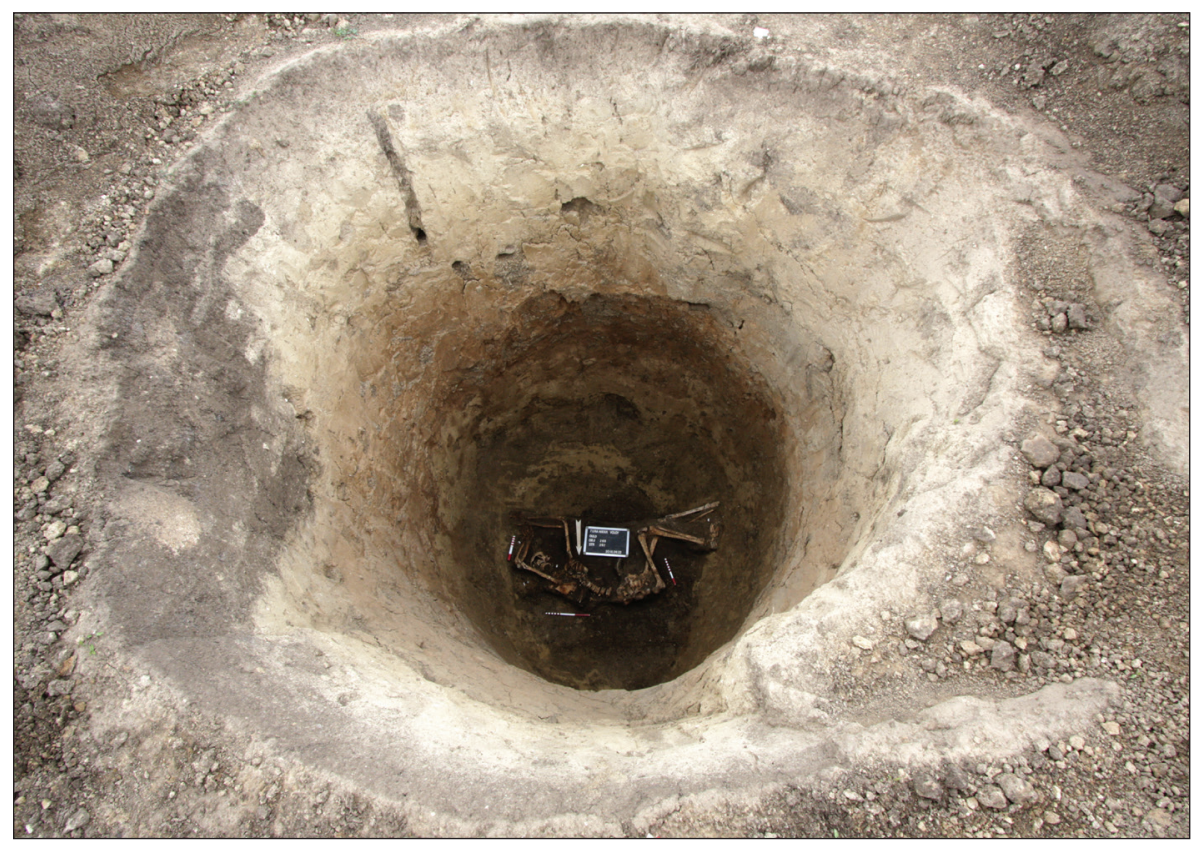

Fig. 12. View of the Early Modern Age pit from above.

\section{Early modern period and the Second World War}

A deep steep-walled pit in the western section of the excavation cradled the remains of a deceased from the early modern period (Fig. 12). During the exploitation of the filling we believed that the feature was from the Late Bronze Age, as many pottery fragments of the period in question were collected. Not much before we planned to suspend its excavation due to the risk of an accident, the first bones were uncovered. The body of the deceased was on its back, with the hands raised above the head and the legs laid to the left. The position of the hands seems to be somehow unnatural, as if the body was simply thrown into the pit. As we were uncovering the body, an iron object came to light from the back of the neck (Fig. 13.2). It will be interesting to identify it after the restoration, and it will probably be possible afterwards to

13 I hereby say thanks to Maxim Mordovin (ELTE - Institute of Archaeological Sciences) for his help in the identification of the coin.

14 The excavation on the western side of the brook was also carried out by the Ferenczy Museum Center in 2018. The leader of the excavation was Tibor Rácz. 
tell what it was and why it was together with the remains of the body. Interestingly, we found some iron objects near the wrists, next to the forearm, and near the ankles, next to the shin (Fig. 13.3, 4), which coloured the bones of the wrist. On the head's right side, three silver coins were found, which corroded to each other (Fig. 13.1). One side read "Patrona Hungariae" with the date of the minting, which was 1638. After lifting the remains, another few coins wrapped into some fabric were located under the left scapula. As the body was not directly on the floor of the pit, its original function was not to bury the dead person. The pit was probably dug through an urn burial, which were frequent in this part of the excavation, and after finishing, the exploited material was filled back into the pit, which would explain the abundant prehistoric pottery its filling had yielded. A thorough investigation into the historical background of a possible murder around the date of the coins awaits a more extensive study.

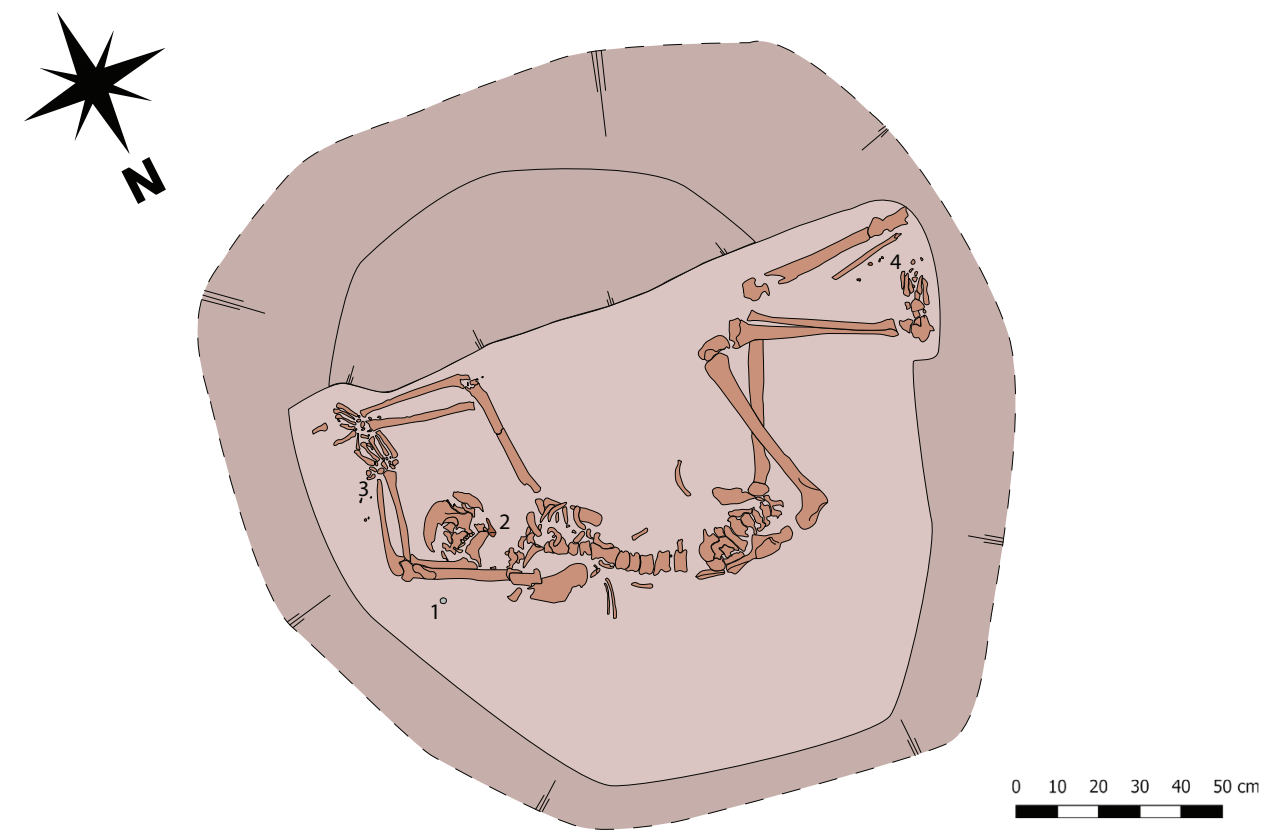

Fig. 13. Drawing of the deceased in the Early Modern Age pit. 1 - silver coin from 1638, 2 - iron object (arrow head?), 3-4 - small round iron objects.

The features from the Second World War came to light together with the prehistoric features. The unearthed features were shallow, rectangular pits with a different, yellowish, mixed filling. From one of them live ammunition, a bullet was uncovered. This coincides with the testimony of János Liszkai and Mária Gólya, who were once residents in this part of Tura. They remembered that the elderly in their childhood had told them about the attack on the train-station nearby which was targeted from the valley next to it.

\section{Summary}

Regarding the prehistoric features, this year's campaign finished with the same results as the previous investigations. The main scientific result is the unearthing of the extensive Árpádian Age settlement. The early modern period pit is also an important addendum to the history of the area. The excavation also revealed that the archaeological site does not extend to the immediate neighbourhood of the Emse Brook, but it starts on the hillside and continues another 400 meters from the dirt-road to the east. 


\section{References}

BÉres, M. 1982: Egy különleges Árpád-kori kemence-típus. Acta Universitatis Szegediensis: acta iuvenum: sectio historica 3, 6-28.

Dinnyés, I. - KőváRI, K. - Kvassay, J. - Miklós, Zs. - Tettamanti, S. - ToRma, I. 2012: Magyarország régészeti topográfiája. Pest megye régészeti topográfiája. Az aszódi és a gödöllői járás. XIII/3. Budapest.

DövÉnYi, Z. (ed.) 2010: Magyarország kistájainak katasztere. Budapest.

Herendi, O. - Sóskuti, K. 2016: Réz-, bronz-, római, Árpád-kori településnyomok és temetkezések Makó, Járandóról. In: Kvassay, J. (ed.): Régészeti kutatások Magyarországon 2011-2014. Budapest, 30-36.

Szalontai, Cs. 2018: 366. Tura határa. In: Kisfaludy, J. - Kvassay, J. - Kreiter, A. (eds.): Régészeti kutatások Magyarországon 2011. Budapest, 186.

VÁLYI, K. 1986: Árpád-kori falusi építmények a szeri monostor területéről. Archaeologiai Értesítő 113, 224-236.

VÁLyI, K. 1992: Külső kemencék Szer Árpád-kori településén. A Móra Ferenc Múzeum Évkönyvei Studia Archaeologica 135-157. 
